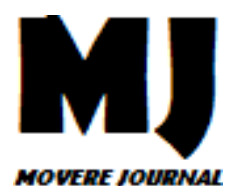

Movere Journal Vol 2 No. 2 Juli 2020 Hal 56-62

MOVERE JOURNAL

http://ojs.stie-tdn.ac.id/index.php/mv

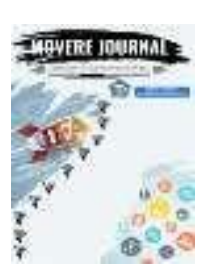

\title{
PENGARUH MANAJEMEN PENGELOLAAN BADAN USAHA MILIK DESA TERHADAP PENINGKATAN PARTISIPASI MASYARAKAT DI DESA BILA RIASE KECAMATAN PITU RIASE KEBUPATEN SIDENRENG RAPPANG
}

\author{
Monalisa Ibrahim \\ Ahmad Mustanir \\ A.Astinah Adnan \\ Nur Alizah P
}

\section{Universitas Muhammadiyah Sidenreng Rappang}

\begin{abstract}
Abstrak: Penelitian ini bertujuan untuk mengetahui pengaruh manajemen pengelolaan Badan Usaha Milik Desa terhadap peningkatan partisipasi masyarakat di Desa Bila Riase Kecamatan Pitu Riase Kabupaten Sidenreng Rappang. Populasi dalam penelitian ini adalah 83 tokoh masyarakat di Desa Bila Riase yang dimana pengambilan sampel yang digunakan yaitu probability sampling, dengan teknik purposive sampling dengan menggunakan rumus Slovin dengan jumlah Sampel 45 tokoh masyarakat, penelitian ini menggunakan metode deksriptif kuantitatif. Teknik pengumpulan data yang digunakan melalui observasi, kuesioner(angket), wawancara,studi pustaka. Teknik analisis data yang digunakan adalah statistik deksriptif, uji kualitas data, uji asumsi klasik dengan menggunakan SPSS 16.0 dan skala likert. Hasil penelitian ini menunjukkan bahwa pengaruh manajemen pengelolaan bumdes dengan nilai 62,12\% dikategorikan "berpengaruh" dengan $\mathrm{t}_{\text {hitung }}$ $\geq \mathrm{t}_{\text {tabel, }}$ atau $9.436 \geq 1683$. Adapun faktor-faktor yang mempengaruhi manajemen pengelolaan BUMDes yaitu partisipasi ( $67 \%$ )sumber daya manusia( $64 \%$ ) dengan hasil akumulasi sebesar 65,5\% atau dikategorikan "berpengaruh". Pengaruh manajemen pengelolan badan usaha milik desa terhadap peningkatan partisipasi masyarakat di Desa Bila Riase Kecamatan Pitu Riase Kabupaten Sidenreng Rappang dengan hasil 50,02\% dikategorikan kurang berpengaruh.
\end{abstract}

Kata kunci: Manajemen Pengelolaan BUMDes dan Partisipasi masyarakat

\section{PENDAHULUAN}

Pendirian BUMDes bertujuan:
(Menteri desa, pembangunan daerah tertinggal, 2015):

a. Meningkatkan perekonomian (c) 2020 STIE TDN. All rights reserved

Corresponding Author: monalisa@umsrappag.ac.id, ahmadmustanir74@gmail.com, andi,astinah,adnan@gmail.com, nuraliza@gmail.com 
Desa;

b. Mengoptimalkan aset Desa agar bermanfaat untuk kesejahteraan Desa;

c. Meningkatkan usaha masyarakat dalam pengelolaan potensi ekonomi Desa;

d. Mengembangkan rencana kerja sama usaha antar desa dan/atau dengan pihak ketiga;

e. Menciptakan peluang dan jaringan pasar yang mendukung kebutuhan layanan umum warga;

f. Membuka lapangan kerja

g. Meningkatkan kesejahteraan masyarakat melalui perbaikan pelayanan umum, pertumbuhan dan pemerataan ekonomi Desa; dan

h. Meningkatkan pendapatan masyarakat Desa dan Pendapatan Asli Desa.

Pemerintah Desa menginginkan dengan pembentukan dan pengelolaan BUMDes dapat meningkatkan kesejahteraan masyarakat, pengembangan potensi desa dan kemandirian perekonomian desa dengan kegiatan dan usaha yang telah di kelola oleh BUMDes dengan memberdayakan masyarakat. Dalam penelitian yang dilakukan oleh Morni Kasila dan Lala M Kalopaking dalam judul partisipasi pemuda desa dalam pengembangan usaha BUMDes Tirta Mandiri dihasilkan beberapa faktor yang mempengaruhi tingkat partisipasi pemuda, faktor yang memiliki hubungan kuat dengan tingkat partisipasi pemuda dalam BUMDes yaitu tingkat komunikasi. Dimana jika komunikasi juga dilakukan dengan baik antara para pengelolah tentunya bisa mengembangkan keikutsertaan masyarakat dalam proses kegiatan BUMDes . Salah satu yang mempengaruhi peningkatan partisipasi masyarakat adalah manajemen pengelolaan BUMDes yang saling berkomunikasi dan bekerja sama dalam proses kegiatan BUMDes.

Partisipasi masyarakat dalam kegiatan pemberdayaan masyarakat kurang serta dalam usaha yang telah di kelola oleh BUMDes. Telah didirikan BUMDes di desa Bila Riase dengan nama Mario Marennu sebagai induk dari BUMDes tersebut, kolam pirsa dan Kuliner Pirsa. Pemerintah desa dan para pengelolah mendirikan BUMDes namun kenyataan hanya beberapa yang digunakan masyarakat. Desa Bila Riase ini terdapat salah satu objek wisata yang terkenal di Kapubaten Sidrap, dimana ketika masyarakat memanfaatkannya dengan menjajahkan usaha dijalan menuju ke tempat itu akan meningkatkan penghasilan masyarakat dan pendapatan desa namun dalam kenyataannya tidak ada masyarakat yang menjajahkan hasil potensi desa seperti yang ada di jalan menuju objek wisata ammani dan Wakka yang ada di Kabupaten Pinrang sehingga kurang dalam pengembangan usaha desa dan pengembangan BUMDes di Desa Bila Riase tidak berjalan dengan optimal sehingga penulis ingin meneliti dengan judul "Pengaruh Manajemen Badan Usaha Milik Desa (BUMDes) terhadap Peningkatan Partisipasi Masyarakat Di Desa Bila Riase Kecamatan Pitu Riase Kabupaten Sidenreng Rappang"

1. Untuk mengetahui Bagaimana Pengaruh Manajemen Pengelolaan Badan Usaha Milik Desa (BUMDes) terhadap peningkatan partisipasi masyarakat Di Desa Bila Riase Kecamatan Pitu Riase Kabupaten Sidenreng Rappang

2. Faktor-faktor yang (C) 2020 STIE TDN. All rights reserved

Corresponding Author: monalisa@umsrappag.ac.id, ahmadmustanir74@gmail.com, andi,astinah,adnan@gmail.com, nuraliza@gmail.com 
mempengaruhi Manajemen Pengelolaan Badan Usaha Milik Desa (BUMDes) terhadap peningkatan partisipasi masyarakat Di Desa Bila Riase Kecamatan Pitu Riase Kabupaten Sidenreng Rappang.

\section{TELAAH LITERATUR DAN PENGEMBANGAN HIPOTESIS}

\section{Administrasi publik}

P. Siagian dalam buku (Kamaruddin Sellang, 2016) administrasi di definisikan sebagai keseluruhan proses kerjasama antara dua orang atau lebih yang didasarkan atas rasionalitas tertentu untuk mencapai tujuan yang telah ditentukan sebelumnya.

\section{Manajemen Pengelolaan}

Bittle \& Bittle dalam (Badrudin, 2013) bahwa alam tataran praktis pengertian manajemen dibagi ke dalam beberapa definisi, antara lain bahwa manajemen menentukan kerja tim, delegasi dan hasil. Manajemen mengakui presensi intuitif, keterampilan subjektif dalam proses manajemen dan pertumbuhan pentingnya pengetahuan yang teruji sebagai satu petunjuk untuk keputusan dan tindakan manajerial. Di sisi lain, manajemen didefinisikan sebagai suatu badan pengetahuan yang dapat diajarkan, diperlukan untuk pelajaran sekolah, lembaga, dan institusiinstitusi. Manajemen adalah apa yang manjer kerjakan dalam pelaksanaan pernana mereka sebagai manajer.

Menurut Siswanto (2005:7) memberi batasan pengelolaan sebagai seni dan ilmu dalam perencanaan, pengorganisasian, pengarahan, pemotivasian dan pengendalian terhadap orang serta mekanisme kerja untuk mencapai tujuan, adapun pengertian dari batasan pengelolaan tersebut sebagai berikut:

a. Perencanaan yaitu suatu proses dan rangkaian kegiatan untuk menetapkan tujuan terlebih dahulu pada suatu jangka waktu/periode tertentu serta tahapan/langkahlangkah yang harus ditempuh untuk mencapai tujuan tersebut.

b. Pengorganisasian yaitu suatu proses dan rangkaian kegiatan dalam pembagian kerja yang direncanaan untuk diselesaikan oleh anggota kelompok pekerjaan, penentuan hubungan pekerjaan yang baik diantara mereka, serta pemberian lingkungan dan fasilitas pekerjaan yang kondusif.

c. Pengarahan yaitu suatu rangkaian kegiatan untuk memberikan petunjuk atau intruksi dari seorang atasan kepada bawahan atau kepada orang yang diorganisasikan dalam kelompok formal dan untuk pencapaian tujuan bersama.

d. Pemotivasian yaitu suatu proses dan rangkaian kegiatan yang dilakukan oleh seorang atasan dalam memberikan inspirasi, semangat, dan kegairahan kerja serta mendorong kepada bawahan untuk dapat melakukan suatu kegiatan yang semestinya.

e. Pengendalian/ pengawasan yaitu suatu proses dan rangkaian kegiatan untuk mengusahakan agar suatu pekerjaan dapat dilaksanakan sesuai dengan rencana yang telah ditetapkan dan tahapan yang harus dilalui. Dengan demikian, apabila ada kegiatan yang tidak sesuai dengan rencana dari tahapan tersebut, diadakan suatu tindakan perbaikan.

(C) 2020 STIE TDN. All rights reserved

Corresponding Author: monalisa@umsrappag.ac.id, ahmadmustanir74@gmail.com, andi,astinah,adnan@gmail.com, nuraliza@gmail.com 
Faktor -faktor yang mempengaruhi Manajemen Badan Usaha Milik Desa. (Asvi, 2017) adapun faktor -faktor nya adalah sebagai berikut

1. Partisipasi Masyarakat. Didalam melaksakanan suatu program atau pun suatu badan usaha sangat dibutuhkan pasrtisipasi masyarakat didalam nya agar semua program yang telah di rencakan oleh suatu organisasi bisa berjalan sebagaimana mestinya, selain partisipsi kondisi masyarakat juga sangat berpengaruh didalam keberhasilan program yang telah di rencanakan

2. Sumber Daya Manusia Sumber daya manusia merupakan seluruh potensi diri atau kemampuan yang miliki oleh manusia serta karakteristik, sosial, ekonomi yang dapat dimanfaatkan untuk keperluan pembangunan dengan segala petensi meliputi kualitas dan kuantitas. Sumber daya manusia merupakan faktor faktor yang sangat penting dalam pelaksanaan suatu kegiatan. Meski perintah -perintah pelaksanaan kegiatan telah diteruskan dengan cermat, jelas, konsisten namun jika dalam prosesnya terjadi kekurangan sumber daya manusia yang diperlukan, maka pelaksanaan program tersebut akan kurang efektif.

\section{Partisipasi Masyarakat}

Menurut Adisasmita (2006) menyatakan, "Partisipasi masyarakat adalah pemberdayaan masyarakat, peran sertanya dalam kegiatan penyusunan perencanaan dan implementasi program/proyek pembangunan, dan merupakan aktualisasi dan kesediaan dan kemauan masyarakat untuk berkorban dan berkontribusi terdahap implementasi program pembangunan"

Menurut Sastropoetro dalam Samad ( 2017 : 284 ) Beberapa bentuk partisipasi meliputi :

1. Partisipasi dalam bentuk tenaga adalah partisipasi yang diberikan dalam bentuk tenaga untuk pelaksanaan usaha-usaha yang dapat menunjang keberhasilan suatu program.

2. Partisipasi dalam bentuk dana adalah partisipasi dalam bentuk menyumbang harta benda, biasanya berupa alat-alat kerja atau perkakas.

3. Partisipasi dalam bentuk informasi. Partisipasi pemberian informasi merupakan transisi antara tidak ada partisipasi dengan penghargaan. Pemberian informasi mengenai hakhak, tanggung jawab, dan pilihanpilihan masyarakat adalah langkah pertama menuju partisipasi masyarakat.

\section{METODE PENELITIAN}

\section{Lokasi dan Waktu Penelitian}

Penelitian ini direncanakan akan laksanakan di Desa Bila Riase Kecamatan Pitu Riase Kabupaten Sidenreng Rappang. Pemilihan lokasi karena melihat adanya Beberapa BUMDes yang sangat perlu dikembangkan agar dapat berdaya guna, memberikan manfaat kepada masyarakat untuk mencapai kehidupan yang lebih sejahtera. Waktu penelitian dilaksanakan selama 2 bulan yaitu pada bulan Februari-April 2020.

\section{Tipe dan Dasar Penelitian}

(C) 2020 STIE TDN. All rights reserved

Corresponding Author: monalisa@umsrappag.ac.id, ahmadmustanir74@gmail.com, andi,astinah,adnan@gmail.com, nuraliza@gmail.com 
Agar penelitian ini lebih terarah serta sesuai dengan tujuan yang diinginkan bersarkan konsep yang diajukan. Maka dasar penelitian yang digunakan adalah Kuantitatif. Yakni pencarian data/informasi dari realitas permasalahan yang ada dengan mengacu pada pembuktian konsep atau teori yang digunakan. Adapun tipe penelitian kuantitatif yang digunakan yaitu deskriptif kuantitatif. Sedangkan jenis data dalam penelitian ini adalah gabungan antara data kuantitatif dengan data kualitatif.

\section{Populasi dan Sampel}

Populasi dalam penelitian ini adalah tokoh masyarakat di Desa Bila Riase Kecamatan Pitu Riase Kabupaten Sidenreng Rappang dari empat Dusun yang berjumlah 83 orang

Adapun sampel dalam penelitian ini menggunakan rumus Slovin sebanyak 45 tokoh masyarakat

\section{Teknik pengumpulan Data}

Untuk memperoleh data yang lebih akurat, sehingga relevan dengan objek penelitian, akan peneliti akan menggunakan teknik pengumpulan data sebagai berikut :

1. Observasi.

Observasi adalah mengadakan pengamatan secara langsung , observasi dapat dilakukan dengan tes, kuesioner, ragam gambar, dan rekaman suara. (Ahmad : 2015). Observasi pada penelitian ini dilakukan di BUMDes desa Bila Riase agar mengetahui manajemen pengelolaan BUMDes dan partisipasi masyarakat.

2. Kuesioner (angket).

Kuesioner adalah sejumlah pertanyaan tertulis yang digunakan untuk memperoleh informasi dari responden dalam arti laporan tentang

pribadinya. (Ahmad :2015). Observasi pada penelitian ini dilakukan dengan membagikan kuesioner kepada masyarakat agar dapat mengetahui bagaimana manajemen pengelolaan BUMDes dan peningkatan partisipasi masyarakat di Desa Bila Riase.

3. Interview (wawancara).

Wawancara adalah proses memperoleh keterangan untuk tujuan penelitian dengan cara tanya jawab sambil bertatap muka antara si penanya atau pewawancara dengan si penjawab atau responden dengan menggunakan alat yang dinamakan intrview guide ( panduan wawancara ). ( Ahmad : 2015 ). ). Observasi pada penelitian ini dilakukan dengan melakukan wawancara dengan stakeholder yang benar-benar mengetahui BUMDes di Desa Bila Riase.

4. Studi Pustaka

Suatu kegiatan membaca dan mengumpulkan literatur yang berkaitan dengan indikator penelitian, baik melalui buku, jurnal, maupun hasil penelitian terdahulu

\section{HASIL PENELITIAN DAN PEMBAHASAN}

Rekapitulasi
Manajemen pengelolaan terdapat
$62,12 \%$ dari $100 \%$ yang diharapkan
maka dari jumlah $62,12 \%$ memiliki
kategori "Baik". Sehingga dapat
disimpulkan bahwa yang paling dalam
indikator manajemen pengelolaan yaitu
perencanaan 37.88\% sehingga perlu
untuk ditingkatkan kedepannya.
Rekapitulasi Indikator partisipasi
masyarakat terdapat $62,3 \%$ dari 100\%
yang diharapkan maka dari jumlah
$62,3 \%$ memiliki kategori "Baik".
Sehingga dapat disimpulkan bahwa
yang paling dalam indikator partisipasi
@ 2020 STIE TDN. All rights reserved

Corresponding Author: monalisa@umsrappag.ac.id, ahmadmustanir74@gmail.com, andi,astinah,adnan@gmail.com, nuraliza@gmail.com 
masyarakat yaitu partisipasi dalam bentuk tenaga $37,7 \%$ sehingga perlu untuk ditingkatkan kedepannya.

Paling penting dalam setiap partisipasi masyarakat adalah bagaimana mereka berpartisipasi atau turut serta secara langsung dalam setiap kegiatan yang dilakukan karena dalam suatu kegiatan dapat dikatakan berhasil jika masyarakat tertarik dan ikut serta dalam kegiatan tersebut. Dengan banyaknya masyarakat yang ikut berpartisipasi dapat dikatakan bahwa manajemen pengelolaan dalam kegiatan tersebut berhasil dikarenakan dapat menarik minat masyarakat. Karena masyarakat dikalangan sekarangan ini mereka sibuk dengan pekerjaannya masing-masing sehingga kurang berpartisipasi ketika ada kegiatan yang dilakukan baik dipemerintah desa maupun di Badan Usaha Milik Desa tersebut.

Rekapitulasi faktor-faktor yang mempengaruhi manajemen terdapat $65,5 \%$ dari $100 \%$ yang diharapkan maka dari jumlah $65,5 \%$ memiliki kategori " baik". Sehingga dapat disimpulkan bahwa yang paling kurang dalam faktor-faktor yang mempengaruhi manajemen pengelolaan yaitu sumber daya manusia sehingga perlu untuk ditingkatkan kedepannya.

Mengetahui jumlah dari kedua variabel yaitu maka dapat dilihat dari Rumus dibawah ini dengan menggunakan Rumus Hasil Ideal sebagai berikut :

$$
\begin{gathered}
=\frac{700+430}{5 \times 10 \times 45} \times 100 \\
=\frac{1130}{5 \times 10 \times 45}=\frac{1130}{2250} \\
=0.50 \times 100 \% \\
=50 \%
\end{gathered}
$$

Jika dilihat dari Rumus diatas maka terdapat 50\% kurang dari $100 \%$ dimana $50 \%$ merupakan Kategori "Kurang Berpengaruh "

Partisipasi masyarakat dalam manajemen pengelolaan BUMDesa tentunya sangat berpengaruh. Dikarenakan masyarakat sebagai ujung tombak suatu keberhasilan kegiatan dan merupakan tujuan dari kegiatan yang dilakukan oleh pengelolah BUMDes. Dimana pengelolaan BUMDes dapat dikatakan berhasil ketika dapat mengikutsertakan masyarakat dalam setiap kegiatannya dan masyarakat tertarik dengan apa saja yang dilakukan oleh para pengelolah BUMDes. Dimana dilihat dari tujuan pendirian BUMDes itu sendiri untuk meningkatkan kesejahteraan masyarakat dan peningkatan potensi desa tentu membutuhkan partisipasi masyarakat.

Tabel Coefficients diperoleh $\mathrm{t}$ hitung $=9.436$ prosedur mencari statistik dengan kriteria
a. Tingkat signifikan $(\mathrm{a}=0,05)$ untuk uji dua pihak
b. Df atau dk (derajat kebebasan) $=$ jumlah data -2 atau 43-2 = 41
c. Sehingga didapat $t_{\text {tabel }}=1.683$

\section{Keputusan}

Ternyata nilai $\mathrm{t}_{\text {hitung }} \geq \mathrm{t}_{\text {tabel, }}$, atau $9.436 \geq 1683$ maka Ho ditolak dan Ha diterima, artinya signifikan. Jadi, manajemen pengelolaan BUMDes berpengaruh/signifikan terhadap peningkatan partisipasi masyarakat di Desa Bila Riase Kecamatan Pitu Riase Kabupaten Sidenreng Rappang.

\section{Pembahasan}

Manajemen pengelolaan BUMDes dapat dikatakan berhasil ketika dapat melibatkan dan meningkatkan partisipasi masyarakat dalam setiap kegiatannya. Dimana (C) 2020 STIE TDN. All rights reserved

Corresponding Author: monalisa@umsrappag.ac.id, ahmadmustanir74@gmail.com, andi,astinah,adnan@gmail.com, nuraliza@gmail.com 
manajemen pengelolaan berfungsi sebagai:

1. Perencanaan merupakan proses kegiatan untuk menetapkan tujuan terlebih dahulu. Dengan perencanaan yang matang dapat memudahkan dalam pencapaian tujuan yang ditetapkan di BUMDes.

2. Pengorganisasian merupakan pembagian kerja yang direncanakan untuk menjalankan tugas dan fungsi masing-masing. Dengan pembagian kerja yang jelas seperti ketua, sekertaris, bendahara dan bagian-bagian lainnya tentu dapat memudahkan dalam melaksanakan tugasnya karena telah dibagi sesuai tugas dan fungsinya tanpa membebankan pekerjaan yang banyak kepada para pengelolah BUMDes.

3. Pengarahan merupakan rangkaian pemberian petunjuk yang dilakukan baik dari pemerintah dan pengelolah BUMDes dengan adanya pengarahan ini dapat memudahkan dalam proses kegiatan BUMDes sehingga kegiatan dapat berjalan sesuai dengan yang telah direncakan.

4. Pemotivasian merupakan proses dan rangkaian kegiatan yang dilakukan dalam memberi inspirasi, semangat dan kegairahan kerja untuk mendorong para pengelolah untuk melakukan suatu kegiatan yang semestinya. Dengan adanya pemberian motivasi kepada pengelolah BUMDes dapat memberikan motivasi dan semangat serta dorongan untuk melakukan inovasi dan menggali ide-ide yang baru lagi untuk pengembangan BUMDes dan lebih giat lagi dalam melakukan tugasnya . Dengan ide-ide yang baru diharapkan dapat menarik minat masyarakat untuk berpartisipasi.

5. Pengendalian merupakan suatu proses dan rangkaian kegiatan untuk mengusahakan agar suatu pekerjaan dapat dilaksanakan sesuai dengan rencana yang telah ditetapkan. Dengan pengendalian melalui pengawasan di pengelolah BUMDes yang sudah baik perlu ditingkatkan untuk melihat sejauh mana tujuan yang telah dicapai dan melihat setiap kegiatan yang dilakukan sesuai dengan apa yang telah direncanakan.

Selain itu, untuk memudahkan manajemen pengelolaan BUMDes tentunya ada faktor-faktor yang mempengaruhinya.

1. Partisipasi masyarakat merupakan pemberdayaan masyarakat, peran sertanya dalam kegiatan penyusunan perencanaan dan implementasi prigram/proyek pembangunan, dan merupakan aktualisasi dan kesedian dan kemauan masyarakat untuk berkorban dan berkontribusi terhadap implementasi program. Didalam melaksanakan suatu program ataupun suatu badan usaha sangat dibutuhkan partisipasi masyarakat didalamnnya agar semua program yang telah direncanakan oleh suatu organisasi bisa berjalan sebagaimana semestinya dan Dengan adanya partisipasi masyarakat manajemen pengelolaan BUMDes dapat (C) 2020 STIE TDN. All rights reserved

Corresponding Author: monalisa@umsrappag.ac.id, ahmadmustanir74@gmail.com, andi,astinah,adnan@gmail.com, nuraliza@gmail.com 
dikatakan berhasil dikarenakan tujuan pendirian BUMDes ini diperuntukkan untuk masyarakat.

2. Sumber daya manusia merupakan seluruh potensi diri atau kemampuan yang dimiliki oleh manusia serta karakteristik,sosial, ekonomi yang dapat dimanfaatkan untuk keperluan pengelolaan dengan segala potensi melalui kualitas dan kuantitas. Dimana sumber daya manusia faktor penting dalam pelaksanaan suatu kegiatan. Dengan adanya kemampuan yang dimiliki dapat memudahkan untuk pengelolaan BUMDes dan menjalankan tugasnya dengan fungsi sesuai dengan kemampuannya. Dengan kurangnya sumber daya manusia yang dimiliki maka pelaksanaan kegiatan BUMDes menjadi kurang efektif.

Dengan adanya manajemen pengelolaan yang baik serta partisipasi masyarakat ada dan kemampuan dari sumber daya manusia dari pengelolah tentunya dapat meningkatkan partisipasi masyarakat tentunya tidak hanya terlibat lansung dalam setiap kegiatan tapi ikut dalam pengembangan BUMDes serta pencapaian tujuan BUMDes. Partisipasi dapat dilihat dari:

1. Partisipasi dalam bentuk tenaga adalah partisipasi yang diberikan dalam bentuk tenaga untuk pelaksanaan usaha-usaha yang dapat menunjang keberhasikan suatu kegiatan. Masyarakat berpartisipasi dalam bentuk tenaga dalam kegiatan dan usaha yang dilakukan oleh BUMDes agar tercapai tujuan pendirian BUMDes yang mana diperuntukkan untuk masyarakat itu sendiri.
2. Partisipasi dalam bentuk dana adalah partisipasi dalam bentuk menyumbangkan harta benda, biasanya berupa alat-alat kerja atau perkakas. Dengan adanya partisipasi masyarakat dalam bentuk dana, harta atau benda tentunya dapat dimudahkan dalam setiap kegiatan BUMDes.

3. Partisipasi dalam bentuk informasi adalah pemberian informasi mengenai hak-hak, tanggung jawab dan pilihan-pilihan masyarakat. Dengan masyarakat menyampaian apa saja yang dibutuhkan tentunya dapat memudahkan pengelolaan dan pengembangan BUMDes yang ditujuannya untuk kesejahteraan masyarakat.

\section{KESIMPULAN}

Berdasarkan hasil penelitian yang telah diuraikan pada bab sebelumnya. Maka dapat disimpulkan bahwa:

1. Pengaruh Manajemen pengelolaan BUMDes terhadap peningkatan partisipasi masyarakat di Desa Bila Riase Kecamatan Pitu Riase Kabupaten Sidenreng Rappang dikategorikan kurang berpengaruh dengan nilai rata-rata $50 \%$

2. Manajemen pengelolaan yang memiliki persentase paling tinggi yaitu pengorganisasian $65,8 \%$ sedangkan persentase yang paling rendah yaitu pengarahan $57,2 \%$

3. Partisipasi masyarakat yang memiliki persentase paling tinggi yaitu partisipasi masyarakat dalam bentuk tenaga $67 \%$ dan memiliki persentase yang sama yaitu partisipasi dalam bentuk dana dan informasi dengan masing-masing $60 \%$. 
4. Faktor yang mempengaruhi manajemen pengelolaan BUMDes yang memiliki persentase tinggi yaitu partisipasi masyarakat $67 \%$ sedangkan persentase paling rendah yaitu sumber daya manusia $64 \%$.

\section{DAFTAR PUSTAKA}

Ahmad Jamaluddin.2015. Metode Penelitian Administrasi Publik Teori Dan Aplikasi (P. gaya Media, Ed.). Yogyakarta.

Antono, H. 2015. Kesiapan Desa Menghadapi Implementasi Undang-Undang Desa. Jurnal Ilmiah Civis, V (1), 737-751.

Asvi, Z. 2017. Manajemen Badan Usaha Milik Desa (BUMDES) Bina Usaha Desa Kepenuhan Barat Kecamatan Kepenuhan Kabupaten Rokan Hulu. 4(2), 115.

Badrudin. 2013. dasar-dasar manajemen bandung: alfabeta.

Fadil, F. 2013. Partisipasi Masyarakat Dalam Musyawarah Perencanaan Pembangunan Di Kelurahan Kotabaru Tengah. II, 251-262. Retrieved from https://ppjp.ulm.ac.id/journal/inde x.php/JIPPL/article/view/897

Fokusmedia, T. 2014. undang-undang desa kelurahan kecamatan (fokus medi).

Hayat. 2017. manajemen pelayanan publik ( raja grafindo Persada, Ed.). jakarta.

Ibrahim Monalisa, Marsita. 2017. Penerapan Fungsi-Fungsi
Manajemen Terhadap Kabupaten Sidenreng Rappang. Januari, 154167

Ibrahim Monalisa . 2018. Penerapan Fungsi-Fungsi Manajemen Terhadap Efektivitas Pengelolaan Badan Usaha Milik Desa Tonrong Rijang Kecamatan Baranti Kabupaten Sidenreng Rappang. 14(2). 279-290.

Ibrahim Monalisa, Dkk. 2019. Peranan camat dan partisipasi masyarakat dalam musyawarah perencanaan pembangunan di Kecamatan Enrekang Kabupaten Enrekang. 5(2).33-48.

2020. Pembangunan Partisipasi dan pemberdayaan masyarakat: Imlementasi penataan Lembaga Kemasyarakatan di Desa.1.112

Keban, T. Yeremias.2004. Enam dimensi strategis Administrasi publik,konsep, Teori dan Isu. Gava Media. Yogyakarta

Koso, J., Ogotan, M., \& Mambo, R. (n.d.). Manajemen pengelolaan BUMDes (Studi di Desa Watulaney Amian Kec. Lembean Timur Kab Minahasa.

Kushartono, E. W.2016. Pengembangan Desa Mandiri Melalui Pengelolaan Badan Usaha Milik Desa (BUMDes ) Fitrie Arianti Universitas Diponegoro Semarang .

Menteri desa, pembangunan daerah tertinggal, dan transmigrasi Republik Indonesia. Peraturan (C) 2020 STIE TDN. All rights reserved

Corresponding Author: monalisa@umsrappag.ac.id, ahmadmustanir74@gmail.com, andi,astinah,adnan@gmail.com, nuraliza@gmail.com 
menteri desa,pembangunan daerah tertinggal, dan transmigrasi RI No. 4 tahu 2015. (2015).

Morni Kasila, lala M. K. 2018. Partisipasi Pemuda Desa Dalam Perkembangan Usaha Bumdes “ Tirta Mandiri " ( Studi di Desa Ponggok , Kecamatan. 2(1), 4358.

Sari, A. M. 2013. Pemberdayaan Sistem Pemerintahan Dan Potensi Desa Pada Kabaputen Pringsewu Berbasis Web. Jurnal Sistem Informasi, 1-8.

Sellang Kamaruddin. (2016). Administrasi dan Pelayanan Publik Antara Teori dan Aplikasi. Penerbit ombak. Yogyakarta.

Statistik, badan pusat. 2018. bpsfile.pdf.
Statistik, badan pusat. (2019). STATISTIK Profil Kemiskinan di Indonesia September 2018. (07), $1-12$.

UU RI No.32 tahun 2004 tentang pemerintahan daerah. , (2004).

Zainuddin, S. (2017). teori-teori mutakhir dalam perspektif ilmu administrasi negara. 